\title{
Pea in Rotation with Wheat Reduced Uncertainty of Economic Returns in Southwest Montana
}

\author{
Perry R. Miller,* Anton Bekkerman, Clain A. Jones, Macdonald H. Burgess, \\ Jeffrey A. Holmes, and Richard E. Engel
}

\begin{abstract}
Pea (Pisum sativum L.) is increasingly being rotated with wheat (Triticum aestivum L.) in Montana. Our objective was to compare economic net returns among wheat-only and pea-wheat systems during an established 4-yr crop rotation. The experimental design included three wheat-only (tilled fallow-wheat, no-till fallow-wheat, no-till continuous wheat) and three no-till peawheat (pea-wheat, pea brown manure-wheat, and pea forage-wheat) systems as main plots, and high and low available $\mathrm{N}$ rates as subplots. Net returns were calculated as the difference between market revenues and operation and input costs associated with machinery, seed and seed treatment, fertilizer, and pesticides. Gross returns for wheat were adjusted to reflect grain protein at "flat" and "sharp" discount/premium schedules based on historical Montana elevator schedules. Cumulative net returns were calculated for four scenarios including high and low available $\mathrm{N}$ rates and flat and sharp protein discount/premium schedules. Pea-wheat consistently had the greatest net returns among the six systems studied. Pea fallow-wheat systems exhibited greater economic stability across scenarios but had greater 4-yr returns (US\$287 ha ${ }^{-1}$ ) than fallow-wheat systems only under the low $\mathrm{N}$ rate and sharp protein discount schedule scenario. We concluded that pea-wheat systems can reduce net return uncertainties relative to wheat-only systems under contrasting $\mathrm{N}$ fertility regimes, and variable wheat protein discount schedules in southwestern Montana. This implies that pea-wheat rotations, which protected wheat yield and/or protein levels under varying $\mathrm{N}$ fertility management, can reduce farmers' exposure to annual economic variability.
\end{abstract}

Summerfallow has been described as the single most destructive agricultural soil management practice due to soil erosion, loss of soil organic matter and soil structure, nitrate N leaching, and soil salinization (Linfield 1902; Larney et al., 1994; Janzen 2001). In the northern Great Plains (NGP), summerfallow has declined steadily since its peak of 17 million ha in the early 1970s to less than 5 million ha (Tanaka et al., 2010). In northeastern Montana (USDA-NRCS Major Land Resource Area [MLRA] 53a), declining summerfallow area has largely been replaced by pulse crops (Fig. 1; Long et al., 2014). However, summerfallow has remained recalcitrant in north central Montana (MLRA 52). Pulse crops are cool-season annual grain legumes, primarily consisting of pea, lentil (Lens culinaris Medik.), and chickpea (Cicer arietinum L.), with economically important production occurring in northern-tier

P.R. Miller, C.A. Jones, J.A. Holmes, and R.E. Engel, Dep. Land Resources and Environ. Sci., Montana St. Univ., 334 Leon Johnson Hall, Bozeman, MT 59717-3120; A. Bekkerman, Dep. Agric. Econ. and Econ., Montana St. Univ., 306 Linfield Hall, Bozeman, MT 59717-2920; and M.A. Burgess Dep. Plant Sci. and Plant Path., Montana St. Univ., Plant Bioscience Bldg., Bozeman, MT 59717-3150. Received 8 Apr. 2014. Accepted 28 Sept. 2014. *Corresponding author (pmiller@montana.edu).

Published in Agron. J. 107:541-550 (2015)

doi:10.2134/agronj14.0185

Available freely online through the author-supported open access option. Copyright $\odot 2015$ by the American Society of Agronomy, 5585 Guilford Road, Madison, WI 53711. All rights reserved. No part of this periodical may be reproduced or transmitted in any form or by any means, electronic or mechanical, including photocopying, recording, or any information storage and retrieval system, without permission in writing from the publisher. states from Washington to North Dakota and in the Canadian prairie provinces from Alberta to Manitoba.

The use of plow-down cover crops, specifically legume green manures, to improve soil fertility is a well-established concept (Power, 1991; Biederbeck et al., 1996, 1998). However, fallow replacement with green manures in the NGP has been historically dismissed in the literature for implementation due to excessive soil water use (Sarvis and Thysall 1936; Ford and Krall 1979; Janzen 2001). More recent use of legume cover crops was also shown to be uneconomical compared with summerfallow in west central Saskatchewan (Brandt 1996), however that region currently includes very little summerfallow. By managing soil water use conservatively and for multiple rotations, lentil green manure in tilled systems increased soil $\mathrm{N}$ contributions to spring wheat in northeastern Montana (Pikul et al., 1997; Allen et al., 2011) and was found to be economically profitable in southwestern Saskatchewan (Zentner et al., 2004). Miller et al. (2006) showed similar promise with chemically killed pea manure in sequence with spring wheat in a notill system in north central Montana but subsequent cropping sequence work showed that wheat yield and protein responses to pea manure were inconsistent (Miller et al., 2011; O'Dea et al., 2013; Burgess et al., 2014). The objective of this study was to compare crop yield and quality parameters and net returns among six 4-yr pea-wheat and wheat-only crop rotations in southwestern Montana.

Abbreviations: MLRA, Major Land Resource Area; NGP, northern Great Plains; NT, no-till. 

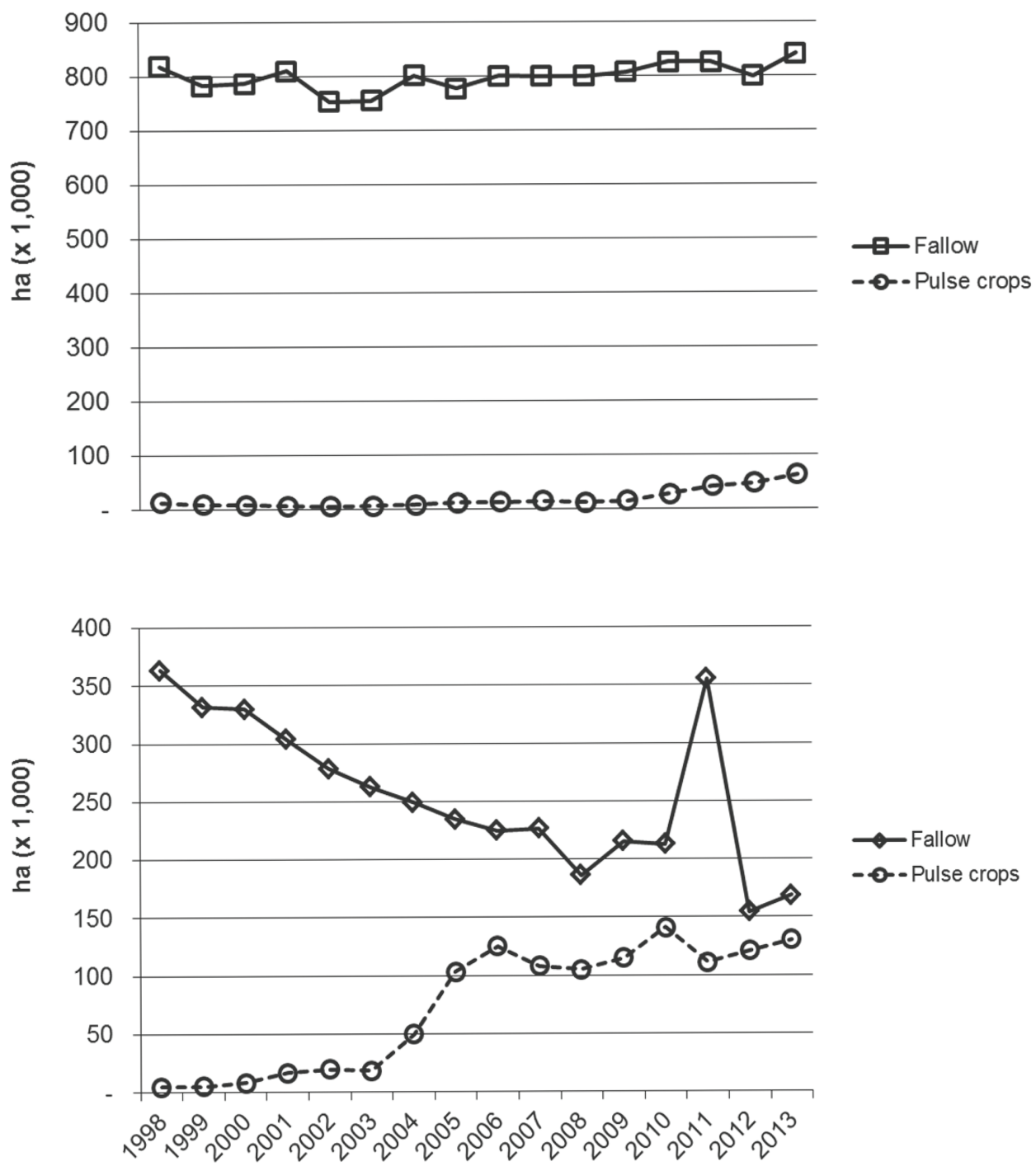

Fig. I. Summerfallow and pulse crop area in north central Montana (MLRA 52--upper panel) and northeastern Montana (MLRA 53a--lower panel) 1998 to 2013. Note: In 20II, spring flooding in MLRA 53a prevented planting of many spring crops.

\section{MATERIALS AND METHODS Site Description}

The agronomic and economic analyses of wheat only and wheat-pea rotations were based on results from a cropping system study at the Montana State University A.H. Post Research Farm $10 \mathrm{~km}$ west of Bozeman, MT ( $\left.45^{\circ} 40.358^{\prime} \mathrm{N}, 111^{\circ} 9.076^{\prime} \mathrm{W}\right)$. This study was initiated in the fall of 2002, and we report on the 2009 to 2012 rotation cycle. The soil is a well-drained Amsterdam silt loam (fine-silty, mixed, superactive, frigid Typic Haplustoll) with $88 \mathrm{~g} \mathrm{~kg}^{-1}$ sand, $825 \mathrm{~g} \mathrm{~kg}^{-1}$ silt, $86 \mathrm{~g} \mathrm{~kg}^{-1}$ clay, $\mathrm{pH} 7.2$ to 7.7 , and $9.0 \mathrm{~g} \mathrm{~kg}^{-1}$ organic $\mathrm{C}$ in the surface $0.1-\mathrm{m}$ soil layer. Table 1 shows monthly total rainfall and average temperature values for the 2009 to 2012 crop-years. The first 3 yr of this 4 -yr cycle had typical precipitation and temperatures for this location; but 2012 was $150 \mathrm{~mm}$ drier and $1.7^{\circ} \mathrm{C}$ warmer than the 30 -yr average.

\section{Experimental Design}

The experiment consisted of six cropping systems (Table 2), two $\mathrm{N}$ levels (full and half), and four replications. The treatments were arranged as a randomized complete block with cropping system as whole plots and $\mathrm{N}$ level as subplots. The whole-plot size was 7.3 by $22 \mathrm{~m}$. The cropping systems were managed as 2-yr rotations during the transition period (20032008) with emphasis on winter crops. We intended to conduct economic and energetic analyses during the transition period but a hailstorm in 2008 removed a key test crop making these analyses irrelevant. Recognizing the need to expand rotations to include a balance of spring and winter crop phases to aid in weed management, the systems were revised in 2009 to 4 -yr crop rotations. Spring crop phases were grown in 2009-2010 and winter crop phases in 2011-2012 (Table 2) which were largely consistent with the previous 6-yr crop sequence and tillage history.

The cropping systems were conceived sequentially, with the "tilled fallow-wheat" System 1 representing the initial condition. System 2 (and all subsequent systems) removed tillage (i.e., no-till) but maintained the same crop rotation (fallow-wheat). System 3 eliminated fallow in an annually cropped wheat system (i.e., continuous wheat). System 4 adds an $\mathrm{N}_{2}$-fixing dicot crop, pea harvested for grain, in rotation with wheat. System 5 managed pea as a cover crop during the summerfallow period, which was removed as forage, and System 6 managed pea as a cover crop that was chemically killed at an immature plant stage (coincident with forage removal) and left all shoot biomass on the soil surface. 
Table I. Monthly precipitation and mean temperature values during the crop year (September-August) at Bozeman, MT, 2009 to 2012.

\begin{tabular}{|c|c|c|c|c|c|c|c|c|c|c|}
\hline \multirow[b]{2}{*}{ Month } & \multicolumn{5}{|c|}{ Monthly precipitation } & \multicolumn{5}{|c|}{ Mean monthly temperature } \\
\hline & LTA† & $2008 / 2009$ & $2009 / 2010$ & $2010 / 2011$ & $2011 / 2012$ & LTA† & $2008 / 2009$ & $2009 / 2010$ & $2010 / 2011$ & $2011 / 2012$ \\
\hline & \multicolumn{5}{|c|}{$\longrightarrow \mathrm{mm} \longrightarrow$} & \multicolumn{5}{|c|}{$\longrightarrow$} \\
\hline Sept.-Mar. & 157 & 146 & 143 & 155 & 113 & - & - & - & - & - \\
\hline Apr. & 45 & 72 & 38 & 63 & 63 & 6.3 & 5.0 & 6.2 & 4.0 & 8.5 \\
\hline May & 71 & 41 & 86 & 80 & 45 & 10.9 & 12.0 & 8.3 & 9.3 & 10.4 \\
\hline June & 71 & 67 & 119 & 82 & 18 & 14.7 & 14.0 & 13.9 & 14.1 & 15.9 \\
\hline July & 36 & 71 & 10 & 22 & 15 & 19.0 & 18.5 & I8.I & 19.3 & 21.4 \\
\hline Aug. & 31 & 38 & 45 & 25 & 7 & 18.4 & 17.9 & 17.3 & 19.8 & 20.5 \\
\hline Total & 411 & 434 & $44 I$ & 427 & 261 & 6.7 & 6.8 & 6.2 & 6.3 & 8.4 \\
\hline
\end{tabular}

† LTA, long-term average: $198 \mathrm{I}$ to 2010 average at the MSU-Bozeman Experimental Farm (Bozeman 6W). Climate data obtained from official National Weather Service station on site.

\section{Crop Management}

Full recommended $\mathrm{N}$ was considered $50 \mathrm{~kg} \mathrm{Mg}^{-1}$ of targeted yield in spring and winter wheat with targeted yields of 4 and $6 \mathrm{Mg} \mathrm{ha}^{-1}$, respectively. Urea-N application was adjusted according to soil nitrate levels measured before planting and assumed pea $\mathrm{N}$ mineralization credits $\left(20 \mathrm{~kg} \mathrm{~N} \mathrm{ha}^{-1}\right.$ for pea harvested as grain and $40 \mathrm{~kg} \mathrm{~N} \mathrm{ha}^{-1}$ for pea cover crop). Table 2 presents the crop cultivars. Seeding rate (live seeds $\mathrm{m}^{-2}$ ) was 80 for spring pea, 100 to 120 for winter pea, and 200 for wheat. All crops received $112 \mathrm{~kg} \mathrm{ha}^{-1}$ of a 50:50 blend of monoammonium phosphate (11-52-0) and potassium sulfate $(0-0-50-$ 18) placed in the furrow with the seed. Urea fertilizer $\mathrm{N}$ was applied to attain full and half recommended rates of total available $\mathrm{N}$, banded $>5 \mathrm{~cm}$ below and to the side of the seed row.

System 1 fallow weed control was conducted in May 2009 with a 2.2-m wide chisel plow (36-cm shovels) at 12 - to $15-\mathrm{cm}$ soil depth, followed by two additional passes through the summer. A final seedbed preparation pass with a 3.3-m wide light duty cultivator (18-cm shovels) with trailing roller baskets operated at 5- to 7-cm soil depth was conducted to firm the soil. In 2011, the tilled fallow system was treated with glyphosate applied in May to match System 2 due to increasing creeping thistle (Cirsium arvense $\mathrm{L}$.) infestation in the tilled fallow system. After that, it was managed similarly to 2009 . The no-till systems (i.e., 2-6) included pre-seed, and occasional post-harvest, applications of glyphosate at 630 to $840 \mathrm{~g}$ a.e. $\mathrm{ha}^{-1}$, and in-crop application of various selective herbicides for broadleaf and/or grassy weed control. Weeds did not interfere importantly with grain yield in this study, with the exception of one plot in System 3 in 2009 that was severely infested with wild oat (Avena fatua L) and was subsequently managed with wild oat herbicides. A commercial custom-fabricated 1.8-m wide no-till plot seeder, with double-disk openers for seed (rear rank) and fertilizer (front rank) application (Fabro Enterprises Ltd., Swift Current, Canada) was used and row spacing alternated from $26 \mathrm{~cm}$ in odd-years to $30 \mathrm{~cm}$ in even years to minimize hair-pinning at seeding. Seeding depth was generally $2.5 \mathrm{~cm}$ below the top of the moist soil to a maximum depth of $5 \mathrm{~cm}$. Aiming for maximum shoot biomass in Systems 5 and 6, pea was chemically terminated at the plump pod stage, before viable seed formation (15 July 2009-spring pea; 28 June 2011-winter pea).

\section{Crop Data Collection}

Pea shoot biomass was measured by clipping two $1-\mathrm{m}^{2}$ samples from each subplot to estimate harvested forage yield in System 5 at a 7 to $9 \mathrm{~cm}$ cutting height and at the soil surface to estimate total green manure shoot biomass for System 6. Weed biomass was harvested separately. In 2009, the weeds fraction was made up almost completely by volunteer wheat from the severe hail event in 2008. Dry matter weight was obtained from shoot biomass samples that were dried for $72 \mathrm{~h}\left(50^{\circ} \mathrm{C}\right)$. Grain yield was determined by combining a single strip in each subplot approximately $1.5-\mathrm{m}$ wide and calculating the exact area from the number and measured length of harvested crop rows. If necessary, grain samples were dried at $50^{\circ} \mathrm{C}$ for $72 \mathrm{~h}$. Dry grain samples were cleaned and dry weight determined by either measuring the grain moisture content with an Infratec 1241 Grain Analyzer (Foss of North America, Eden Prairie, $\mathrm{MN}$ ) or in a representative subset of oven-dried samples for each crop. Grain N content was measured either with the Infratec 1241 Grain Analyzer or a LECO CNS analyzer (LECO Corp., St. Joseph, MI) and reported on a dry matter basis. A conversion factor of 5.7 was used to convert from grain $\mathrm{N}$ to protein in wheat (Jones, 1941). Grain N yield was obtained by multiplying the dry weight of the wheat grain by grain $\mathrm{N}$ concentration.

\section{Soil Data Collection}

Soil cores were taken typically 2 to 4 wk before seeding only for systems requiring $\mathrm{N}$ fertilizer application (i.e., Systems 3 and 4 in odd years, and all systems in even years). Two cores per subplot were taken with a 50-mm diam. hand auger in depth increments of 0 to $0.15,0.15$ to 0.3 , and 0.3 to $0.6 \mathrm{~m}$, and then composited (two cores per sample). Soil was dried $\left(50^{\circ} \mathrm{C}\right)$ and

Table 2. Cultivar and sequence of crops for six cropping systems during 2009 to 2012 at Bozeman, MT.

\begin{tabular}{|c|c|c|c|c|c|c|}
\hline \multirow[b]{2}{*}{ Year } & \multicolumn{6}{|c|}{ Cropping system } \\
\hline & 1 & 2 & 3 & 4 & 5 & 6 \\
\hline 2009 & Till fallow & NT† fallow & Vida spring wheat & $\longrightarrow A$ & g pea - & 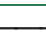 \\
\hline \multicolumn{7}{|l|}{2010} \\
\hline 2011 & Till fallow & NT fallow & Vida spring wheat & Windham winter peał & \multicolumn{2}{|c|}{ Melrose Austrian winter pea } \\
\hline 2012 & 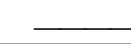 & & Yellow & winter wheat & & \\
\hline
\end{tabular}

$\dagger$ NT, no-till.

$\ddagger$ Two of four reps resown to spring pea due to winterkill. Windham pea is a semi-leafless semi-dwarf feed quality grain pea; Melrose is a viny normal leafed variety more suited for forage and green manure. 
analyzed for nitrate $\mathrm{N}(1 \mathrm{M} \mathrm{KCl})$ with Cd reduction flow injection (Willis, 1980) at all depths. Each spring near 1 May the depth of moist soil was determined using a 1.4-m (54-in) Paul Brown soil moisture probe (Brown, 1959) that had been modified (additional $0.3 \mathrm{~m}$ in length and a standard ball without corkscrew at the tip). The probe was inserted three times per subplot and the depth of moist soil was recorded in a systematic pattern starting at the front of the plot in the south-central seeder pass and proceeding diagonally at intervals toward the rear of the plot in the north-central seeder pass. These three values were averaged to estimate the depth of wet soil per subplot. In 2009, due to very wet spring soil conditions, all Brown probing in the first two reps occurred at maximum depth and so was discontinued.

\section{Statistical and Economic Analyses}

Statistical analyses for the balanced experimental designs without missing data were conducted using JMP 8 (SAS Institute, 2008) using the standard least squares linear regression model. Blocks were considered random while System and N fertility rate were "fixed." Soil nitrate N during 2009 to 2012 was analyzed for all systems in "even" years and only for System 3 in odd-numbered years. Spring moist soil depth during 2010 to 2012 was analyzed with the full model. For both soil nitrate $\mathrm{N}$ and moist soil depth, orthogonal contrasts were computed for fallow-wheat ( 1 and 2) vs. pea fallow-wheat systems (5 and 6).

The economic analyses assume a risk-neutral representative producer who can choose a cropping system and fertilizer rate from the choice set described above based on the expected 4 yr discounted present value of net returns from each system. These aggregate net returns to land and management were calculated for the 2009 to 2012 period as the difference between market revenues (excluding federally-subsidized crop insurance and other government program payments) and operation and input costs associated with machinery, seed and seed treatment, fertilizer, and pesticides. Future values of net returns were discounted by $0.79 \%$, which is the 3 Jan. 2013 5-yr U.S. Treasury bond rate. Machinery cost estimates for air seeders, sprayers, tillage equipment, and harvesters were based on the annually published custom work rates for western North Dakota, which represent field-scale operations (Aakre 2013) rather than the plot-scale machinery used to conduct this study and are assumed to incorporate other costs (e.g., storage, management) that a typical farmer would observe. Seed and seed treatment cost information was obtained as direct quotes from seed suppliers in Montana, assuming delivery to Bozeman. Fertilizer costs were estimated using bi-annual price data collected by the Montana Department of Agriculture, who maintain records from all fertilizer dealers as part of a fertilizer check-off program in Montana (Montana Dep. Ag. Fertilizer Program, unpublished data, 2013). Herbicide costs used in this analysis were based on 2012 retail prices published for North Dakota (Zollinger 2013) and actual local market prices were used for adjuvants and insecticide costs. It is important to note that these data were assumed to represent typical costs for an average Montana farm, but variation (e.g., volume discounts) that could lower these costs may exist.

All crop sales are assumed to occur on the spot market (rather than as a result of a forward contract) at the "farm gate." Wheat grain values were determined as the state average reported spot price for spring wheat at $159 \mathrm{~g} \mathrm{~kg}^{-1}(14.0 \%)$ protein $\left(\$ 278-282 \mathrm{Mg}^{-1}\right)$ and winter wheat at $136 \mathrm{~g} \mathrm{~kg}^{-1}(12.0 \%)$ protein $\left(\$ 230-232 \mathrm{Mg}^{-1}\right)$, for a 3-yr calendar period centered on the harvest year, based on observed spot prices at Montana elevators (USDA Agricultural Marketing Service). Gross returns for wheat were adjusted to reflect test weight and grain protein discount/premium schedules with protein premiums capped at $182 \mathrm{~g} \mathrm{~kg}^{-1}$ grain protein based on "average" elevator schedules. Discounts for low grain test weight occurred only in 2012 and were obtained from personal communications with 20 elevators across Montana. Wheat protein discount/premium relations were estimated using weekly price data for spring and winter wheat with different protein levels from 40 Montana grain elevators during 2001 to 2011 (Cash Grain Bids, Inc., unpublished data, 2012). During this period, 7 yr were observed to have flat discount/premium schedules and $5 \mathrm{yr}$ had sharp protein discount/premium schedules. The estimated flat and sharp protein discount schedules for spring and winter wheat that capture the likely protein discounts depending on alternative supply and demand market conditions are as follows:

Equation SW- Flat: Discount $=-30494+$ $41874 \times$ Protein $-13898 \times$ Protein $^{2}$

Adjusted $R^{2}: 0.50$

Equation SW- Sharp: Discount $=-96223$

$+128149 \times$ Protein $-40622 \times$ Protein $^{2}$

Adjusted $R^{2}: 0.77$

Equation WW- Flat: Discount $=$ $-4273+4077 \times$ Protein

Adjusted $R^{2}: 0.42$

Equation WW- Sharp: Discount $=$ $-14105+13311 \times$ Protein

Adjusted $R^{2}: 0.70$

where the discount is $\$ \mathrm{Mg}^{-1}$ and protein is $\mathrm{g} \mathrm{kg}^{-1}$ or,

Equation SW- Flat: Discount $=-829.92$

$+100.29 \times$ Protein $-2.93 \times$ Protein $^{2}$

Equation SW- Sharp: Discount $=-2618.75$

$+306.91 \times$ Protein- $\%-8.56 \times$ Protein $^{2}$

Equation WW- Flat: Discount $=$ $-116.31+9.77 \times$ Protein

Equation WW- Sharp: Discount $=$ $-383.891+31.88 \times$ Protein 
Table 3. Measured moist spring soil depth (max. = $137 \mathrm{~cm}$ ) with Paul Brown soil probe under "Full" and "Half" recommended $\mathrm{N}$ fertility regimes at Bozeman, MT, 2009 to 2012.

\begin{tabular}{|c|c|c|c|c|}
\hline \multirow[b]{2}{*}{ Treatment effect } & \multicolumn{4}{|c|}{ Year } \\
\hline & $2009 \dagger$ & 2010 & 2011 & 2012 \\
\hline Block & - & 0.19 & 0.59 & ns \\
\hline System & - & 0.06 & $<0.01$ & $<0.01$ \\
\hline $\mathrm{N}$ level & - & 0.90 & 0.67 & 0.96 \\
\hline Sys $\times N$ & - & 0.90 & 0.74 & 0.23 \\
\hline \multicolumn{5}{|l|}{ 4-yr Systems (2009-20I0-20II-20I2) } \\
\hline I.Till fllw-swht-fllw-wwht & - & $>137$ & 130 & 136 \\
\hline 2. No-till (NT) fllw-swht-fllw-wwht & - & $>137$ & 135 & $>137$ \\
\hline 3. NT swht-swht-wwht-wwht & - & 130 & 123 & 111 \\
\hline 4. NT spea-swht-wpea-wwht & - & 130 & 126 & 96 \\
\hline 5. NT spfrg-swht-wpfrg-wwht & - & 134 & 124 & 127 \\
\hline 6. NT spmnr-swht-wpmnr-wwht & - & 134 & 107 & 120 \\
\hline LSD 0.10 & & 5 & 9 & 17 \\
\hline \multicolumn{5}{|l|}{$\mathrm{N}$ level } \\
\hline Full & - & 134 & 125 & 121 \\
\hline Half & - & 134 & 124 & 121 \\
\hline \multicolumn{5}{|l|}{ Contrast } \\
\hline (Sys I,2) vs. (Sys 5,6) & - & 0.83 & $P<0.01$ & $P<0.01$ \\
\hline Fallow-wheat & - & 137 & 133 & 136 \\
\hline Pea fallow-wheat & - & 134 & 115 & 124 \\
\hline
\end{tabular}

† Brown probe soil moisture readings were not taken in 2009 due to excessive soil wetness. Several probings were done at the site and all showed a full soil water profile. $\ddagger$ fllw, fallow; swht, spring wheat; wwht, winter wheat; spea, spring pea; wpea, winter pea; spfrg, spring pea forage; wpfrg, winter pea forage; spmnr, spring pea manure; wpmnr, winter pea manure.

where the discount is $\$ \mathrm{bu}^{-1}$ and protein is percent at standard $12 \%$ grain moisture. The specifications were chosen out of a set of alternative models based both on the best in-sample and out-of-sample prediction accuracy measures. A farmer is not expected to be able to predict whether market prices will be characterized by flat or sharp discount schedules at seeding.

Prices for all other crops were based on a 2-yr rolling average beginning in the year of harvest. Pea values (speckled spring pea at
$\$ 287 \mathrm{Mg}^{-1}$ and speckled winter pea at $\$ 496 \mathrm{Mg}^{-1}$ ) were based on the purchase price for similar commodities by a local buyer in Gallatin Valley (J. McDonnell, Circle S Seeds Ltd., personal communication, 2010, 2012). Pea forage was valued at $\$ 49.61 \mathrm{Mg}^{-1}\left(\$ 45\right.$ ton $\left.^{-1}\right)$ based on local quotes for "in the field" sales of similar quality forage. Discounted present values of net returns to land and management were summed for all treatments during 2009 to 2012 (i.e., cumulative) and analyzed as other parameters described above.

Table 4. Pre-seed soil nitrate $\mathrm{N}$ to $0.6 \mathrm{~m}$ ( $\mathrm{kg} \mathrm{N}$ ha-l) for crops receiving fertilizer $\mathrm{N}$ under "Full" and "Half" recommended $\mathrm{N}$ fertility regimes at Bozeman, MT, 2009 to 2012 .

\begin{tabular}{|c|c|c|c|c|}
\hline Treatment effect & 2009 & 2010 & 2011 & 2012 \\
\hline Sampling date & 25 Mar. 2009 & I Apr. 2010 & 3 Sept. 2010 & 8 Sept. 2011 \\
\hline Block & 0.12 & 0.57 & 0.69 & 0.41 \\
\hline System & - & $<0.01$ & - & $<0.01$ \\
\hline $\mathrm{N}$ level & 0.35 & 0.20 & 0.03 & 0.32 \\
\hline Sys $\times N$ & - & 0.87 & - & 0.88 \\
\hline \multicolumn{5}{|l|}{ 4-yr Systems $\dagger$} \\
\hline I.Till fllw-swht-fllw-wwht & - & 53 & - & 42 \\
\hline 2. No-till (NT) fllw-swht-fllw-wwht & - & 53 & - & 29 \\
\hline 3. NT swht-swht-wwht-wwht & 11 & 33 & 18 & 7 \\
\hline 4. NT spea-swht-wpea-wwht & - & 42 & - & 14 \\
\hline 5. NT spfrg-swht-wpfrg-wwht & - & 68 & - & 41 \\
\hline 6. NT spmnr-swht-wpmnr-wwht & - & 82 & - & 43 \\
\hline LSD 0.10 & & 12 & & 6 \\
\hline \multicolumn{5}{|l|}{$\mathrm{N}$ level } \\
\hline Full & 12 & 58 & 29 & 30 \\
\hline Half & 10 & 52 & 8 & 28 \\
\hline \multicolumn{5}{|l|}{ Orthogonal contrast } \\
\hline (Sys I,2) vs. (Sys 5,6) & - & $P<0.01$ & - & $P=0.02$ \\
\hline Fallow-wheat & & 53 & & 36 \\
\hline Pea fallow-wheat & & 75 & & 42 \\
\hline
\end{tabular}

$\dagger$ fllw, fallow; swht, spring wheat; wwht, winter wheat; spea, spring pea; wpea, winter pea; spfrg, spring pea forage; wpfrg, winter pea forage; spmnr, spring pea manure; wpmnr, winter pea manure. 


\section{RESULTS AND DISCUSSION}

\section{Climatic Context}

There exists uncertainty as to how the following results from a southwestern Montana location relate to the main wheat growing region of north central Montana. Annual precipitation totals average from 250 to $350 \mathrm{~mm}$ in north central Montana, generally supporting 1 to $2 \mathrm{Mg} \mathrm{ha}^{-1}$ lower wheat yield goals than were targeted at this site near Bozeman. Total precipitation and average annual temperature values during 2009 to 2011 were very near the 30 -yr average of $410 \mathrm{~mm}$ and $6.7^{\circ} \mathrm{C}$ for this location (Table 1). It is relevant to note that the major difference in precipitation between Bozeman and north central Montana occurs outside the growing season. For example, compared to four representative locations (Chester, Great Falls, Havre, Shelby) spanning the north central Montana region, the 30-yr (1981-2010) average annual precipitation in Bozeman ranged 10 to $40 \mathrm{~mm}$ greater during the growing season (May-July). More importantly, precipitation in the remaining 9 mo averaged 25 to $100 \mathrm{~mm}$ greater, enabling greater over winter soil water storage at Bozeman. Stored soil water is an important benefit to wheat growth but is less so for pea growth due to its shallow rooting habit (Miller and Holmes, 2012). Contrasting with the three normal years, 2012 was the driest and warmest crop-year during the period of record ( $47 \mathrm{yr}$ ) at this location (Table 1). In particular, shortage of rain coupled with unusually warm temperatures in June compromised yield formation in the 2012 winter wheat crop, which was below the yield target of

Table 5. Annual costs per hectare for machine use, seed + fungicidal treatment or rhizobial inoculant, fertilizer, and pesticides for six cropping systems managed with full and half available N rates at Bozeman, MT, 2009 to 2012.

\begin{tabular}{|c|c|c|c|c|c|c|}
\hline System phase & N Fertilizer rate & Machinery & Seed + Treat & Fertilizer & Pesticide & Total \\
\hline & \multicolumn{6}{|c|}{$\underline{2009}$} \\
\hline I.Till fallow & - & 91 & 0 & 0 & 0 & 91 \\
\hline 2. No-till (NT) fallow & - & 54 & 0 & 0 & 30 & 84 \\
\hline \multirow[t]{2}{*}{ 3. NT spring wheat } & Full & 133 & 35 & 316 & 52 & 536 \\
\hline & Half & 133 & 35 & 188 & 52 & 408 \\
\hline 4. NT spring pea & - & 143 & 79 & 79 & 54 & 356 \\
\hline 5. NT spring pea forage & - & 67 & 44 & 79 & 22 & 212 \\
\hline \multirow[t]{2}{*}{ 6. NT spring pea manure } & - & 54 & 44 & 79 & 10 & 188 \\
\hline & \multicolumn{6}{|c|}{$\underline{2010}$} \\
\hline \multirow[t]{2}{*}{ I. Spring wheat } & Full & 151 & 37 & 210 & 86 & 484 \\
\hline & Half & 151 & 37 & 111 & 86 & 385 \\
\hline \multirow[t]{2}{*}{ 2. Spring wheat } & Full & 133 & 37 & 210 & 82 & 462 \\
\hline & Half & 133 & 37 & 111 & 82 & 363 \\
\hline \multirow[t]{2}{*}{ 3. Spring wheat } & Full & 133 & 37 & 227 & 82 & 477 \\
\hline & Half & 133 & 37 & 136 & 82 & 388 \\
\hline \multirow[t]{2}{*}{ 4. Spring wheat } & Full & 133 & 37 & 215 & 82 & 464 \\
\hline & Half & 133 & 37 & 109 & 82 & 361 \\
\hline \multirow[t]{2}{*}{ 5. Spring wheat } & Full & 133 & 37 & 175 & 82 & 427 \\
\hline & Half & 133 & 37 & 72 & 82 & 324 \\
\hline \multirow[t]{3}{*}{ 6. Spring wheat } & Full & 138 & 37 & 161 & 84 & 420 \\
\hline & Half & 138 & 37 & 64 & 84 & 324 \\
\hline & \multicolumn{6}{|c|}{$\underline{2011}$} \\
\hline I.Till fallow & - & 84 & 0 & 0 & 12 & 96 \\
\hline 2. NT fallow & - & 44 & 0 & 0 & 35 & 79 \\
\hline \multirow[t]{2}{*}{ 3. NT winter wheat } & Full & 148 & 52 & 309 & 86 & 595 \\
\hline & Half & 148 & 52 & 173 & 86 & 459 \\
\hline 4. NT winter pea† & - & 161 & 119 & 62 & 72 & 412 \\
\hline 5. NT winter pea forage & - & 99 & 64 & 62 & 62 & 287 \\
\hline \multirow[t]{2}{*}{ 6. NT winter pea manure } & - & 99 & 64 & 62 & 62 & 287 \\
\hline & \multicolumn{6}{|c|}{$\underline{2012}$} \\
\hline \multirow[t]{2}{*}{ I.Winter wheat } & Full & 148 & 44 & 341 & 30 & 563 \\
\hline & Half & 148 & 44 & 165 & 30 & 388 \\
\hline \multirow[t]{2}{*}{ 2.Winter wheat } & Full & 148 & 44 & 358 & 30 & 580 \\
\hline & Half & 148 & 44 & 180 & 30 & 403 \\
\hline \multirow[t]{2}{*}{ 3.Winter wheat } & Full & 161 & 44 & 385 & 62 & 652 \\
\hline & Half & 161 & 44 & 207 & 62 & 474 \\
\hline \multirow[t]{2}{*}{ 4.Winter wheat } & Full & 148 & 44 & 353 & 30 & 576 \\
\hline & Half & 148 & 44 & 173 & 30 & 395 \\
\hline \multirow[t]{2}{*}{ 5.Winter wheat } & Full & 148 & 44 & 309 & 30 & 534 \\
\hline & Half & 148 & 44 & 126 & 30 & 348 \\
\hline \multirow[t]{2}{*}{ 6. Winter wheat } & Full & 148 & 44 & 294 & 30 & 516 \\
\hline & Half & 148 & 44 & 114 & 30 & 336 \\
\hline
\end{tabular}

$\dagger$ Two of four reps were resown to spring pea due to winterkill, which increased costs. 
$6 \mathrm{Mg} \mathrm{ha}^{-1}$ by 0.9 to $3.3 \mathrm{Mg} \mathrm{ha}^{-1}$ across systems. Thus, these research results need to be considered in a climatic context ranging from normal (2009-2011) to much drier and warmer than normal (2012) in southwestern Montana. Historical review of annual precipitation totals at this site reveals a pattern of about 1:4:1 for $>10 \%$ drier:within $10 \%$ of average: $>10 \%$ wetter. That is not importantly different from the 1:3:0 ratio of years observed during this 4 -yr crop rotation cycle.

\section{Crop Production and Quality}

Following an imposed transition period, the six cropping systems continued rotation of crop types (i.e., fallow, wheat, or pea) that were consistent with the previous 6 yr. Similar transition periods were reported elsewhere in the semiarid northern Great Plains, for spring wheat in minimum till systems using lentil as a green manure every other year (Allen et al., 2011) or every third year (Zentner et al., 2004). The depth of moist soil

Table 6. Nitrogen fertilizer rate, yield (grain, forage, or biomass), protein, and economic returns per hectare, including test weight and protein adjustments for wheat, for six cropping systems managed with full and half available N rates at Bozeman, MT, 2009 to 2012.

\begin{tabular}{|c|c|c|c|c|c|c|c|}
\hline System phase & Fertilizer rate & Yield & Protein & Grosst return & TW adjust & FlatPro Prem/Disc & SharpPro Prem/Disc \\
\hline & $\mathrm{kg} \mathrm{N} \mathrm{ha}^{-1}$ & $\mathrm{Mg} \mathrm{ha}^{-1}$ & $\mathrm{~g} \mathrm{~kg}^{-1}$ & $\longrightarrow$ & 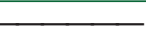 & $\mathrm{ha}^{-1}$ & \\
\hline & \multicolumn{7}{|c|}{$\underline{2009}$} \\
\hline \multirow[t]{2}{*}{ 3. No-till (NT) spring wheat } & 189 & $3.49 * *$ & $133 * *$ & $1102^{* *}$ & 0 & $-22 * *$ & $-79 * *$ \\
\hline & 91 & 2.37 & 108 & 748 & 0 & -89 & -304 \\
\hline \multirow[t]{2}{*}{ 4. NT spring pea } & 5 & 1.93 & 244 & 630 & $-\ddagger$ & - & - \\
\hline & 5 & 1.99 & 250 & 652 & - & - & - \\
\hline \multirow[t]{2}{*}{ 5. NT spring pea forage } & 5 & 2.98 & 167 & 148 & - & - & - \\
\hline & 5 & 3.13 & 181 & 156 & - & - & - \\
\hline \multirow[t]{3}{*}{ 6. NT spring pea manure } & 5 & 3.81 & 188 & 0 & - & - & - \\
\hline & 5 & 3.85 & 188 & 0 & - & - & - \\
\hline & \multicolumn{7}{|c|}{$\underline{2010}$} \\
\hline \multirow[t]{2}{*}{ I. Spring wheat } & 145 & $3.42 * *$ & $149 * *$ & $1070 * *$ & 0 & $-20 * *$ & $-69 * *$ \\
\hline & 50 & 2.32 & 114 & 724 & 0 & -106 & -361 \\
\hline \multirow[t]{2}{*}{ 2. Spring wheat } & 145 & $3.73^{* *}$ & $145^{* *}$ & $1163^{* *}$ & 0 & $-35 * *$ & $-126 * *$ \\
\hline & 50 & 2.65 & 118 & 830 & 0 & -106 & -361 \\
\hline \multirow[t]{2}{*}{ 3. Spring wheat } & 160 & $2.80 * *$ & $144^{* *}$ & $874 * *$ & 0 & $-32 * *$ & $-114 * *$ \\
\hline & 75 & 1.86 & 111 & 583 & 0 & -96 & -321 \\
\hline \multirow[t]{2}{*}{ 4. Spring wheat } & 148 & $3.64 * *$ & $150 * *$ & $1136^{* *}$ & 0 & $-17^{* *}$ & $-64 * *$ \\
\hline & 48 & 2.80 & 129 & 877 & 0 & -74 & -257 \\
\hline \multirow[t]{2}{*}{ 5. Spring wheat } & 112 & $3.70 * *$ & $145^{* *}$ & $1156 * *$ & 0 & $-35^{* *}$ & $-124 * *$ \\
\hline & 12 & 2.74 & 129 & 857 & 0 & -74 & -254 \\
\hline \multirow[t]{3}{*}{ 6. Spring wheat } & 98 & $4.06 \S$ & $159 * *$ & $1267 \S$ & 0 & $5 * *$ & $22^{* *}$ \\
\hline & 5 & 3.64 & $|4|$ & 1136 & 0 & -52 & -180 \\
\hline & \multicolumn{7}{|c|}{$\underline{2011}$} \\
\hline \multirow[t]{2}{*}{ 3. NT winter wheat } & 245 & 3.56 & $133^{* *}$ & 924 & -25 & 20 *** & $57^{* *}$ \\
\hline & 114 & 3.14 & 104 & 815 & -12 & -20 & -72 \\
\hline \multirow[t]{2}{*}{ 4. NT winter pea II } & 5 & 1.80 & - & 978 & - & - & - \\
\hline & 5 & 1.99 & - & 1082 & - & - & - \\
\hline \multirow{2}{*}{ 5. NT winter pea forage } & 5 & 3.06 & 233 & 178 & - & - & - \\
\hline & 5 & 3.69 & 236 & 215 & - & - & - \\
\hline \multirow[t]{3}{*}{ 6. NT winter pea manure } & 5 & 3.14 & 213 & 0 & - & - & - \\
\hline & 5 & 4.74 & 206 & 0 & - & - & - \\
\hline & \multicolumn{7}{|c|}{$\underline{2012}$} \\
\hline \multirow[t]{2}{*}{ I.Winter wheat } & 230 & $4.4 I \S$ & $142 * *$ & $1136 \S$ & -2 & $42^{* *}$ & $126 * *$ \\
\hline & 86 & 4.63 & 116 & 1193 & 0 & -5 & -27 \\
\hline \multirow[t]{2}{*}{ 2.Winter wheat } & 245 & $4.83 \S$ & $|4|$ ** & $1245 \S$ & -2 & $40 * *$ & $|2|^{* *}$ \\
\hline & 97 & 5.13 & 107 & $|32|$ & 0 & -25 & -89 \\
\hline \multirow[t]{2}{*}{ 3.Winter wheat } & 266 & $2.65^{* *}$ & 156 ** & $684^{* *}$ & $-7 \S$ & $40 * *$ & $124 * *$ \\
\hline & 120 & 3.36 & 110 & 867 & 0 & -12 & -47 \\
\hline \multirow[t]{2}{*}{ 4.Winter wheat } & 240 & $3.20 \S$ & $158^{* *}$ & $825^{*}$ & $-12 \S$ & $49 * *$ & $156^{* *}$ \\
\hline & 92 & 3.48 & 124 & 897 & -2 & 5 & 12 \\
\hline 5.Winter wheat & 205 & $4.08 \S$ & $|5|^{* *}$ & $1052^{*}$ & $-15^{* *}$ & $52 * *$ & $\left.16\right|^{* *}$ \\
\hline & 53 & 4.34 & 122 & 1119 & 0 & 5 & 10 \\
\hline 6.Winter wheat & 191 & $4.09 * *$ & $154 * *$ & $1052^{* *}$ & $-15^{* *}$ & $54 * *$ & $173 * *$ \\
\hline & 42 & 4.50 & 124 & 1158 & -2 & 7 & 17 \\
\hline
\end{tabular}

** Significant difference between $\mathrm{N}$ fertilizer rates at $P<0.01$.

$\dagger$ Gross return calculated based on 14.0\% protein Dark Northern Spring Wheat and 12.0\% protein Hard Red Winter Wheat.

$\ddagger$ Not applicable to crops other than wheat.

$\S$ Significant difference between $\mathrm{N}$ fertilizer rates at $P<0.10$.

II Two of four reps were resown to spring pea due to winterkill, which increased costs and reduced net returns. 
Table 7. Cumulative 4-yr discounted present value of net returns per hectare to labor and land for six cropping systems managed with Full and $\mathrm{Half} \mathrm{N}$ fertility and analyzed under Sharp and Flat wheat protein premium/discount schedules at Bozeman, MT, 2009 to 2012.

\begin{tabular}{|c|c|c|c|c|}
\hline System & Full N,Flat & Full N,Sharp & Half N,Flat & Half N,Sharp \\
\hline I.Till fallow-wheat & 969 & 1001 & 824 & 553 \\
\hline 2. No-till (NT) fallow-wheat & 1177 & 1167 & 1063 & 749 \\
\hline 3. NT continuous wheat & 1276 & 1259 & 1028 & 508 \\
\hline 4. NT pea-wheat & 1748 & 1807 & |87| & 1696 \\
\hline 5. NT pea forage-wheat & 1054 & 1073 & 1078 & 905 \\
\hline 6. NT pea manure-wheat & 935 & 1064 & 1089 & 971 \\
\hline LSD 0.10 & 326 & 324 & 269 & 272 \\
\hline \multicolumn{5}{|l|}{ Contrast } \\
\hline (Sys I,2) vs. (Sys 5,6 ) & $P=0.56$ & $P=0.91$ & $P=0.22$ & $P=0.02$ \\
\hline Fallow-wheat & 1073 & 1084 & 944 & 651 \\
\hline Pea fallow-wheat & 994 & 1069 & 1083 & 938 \\
\hline
\end{tabular}

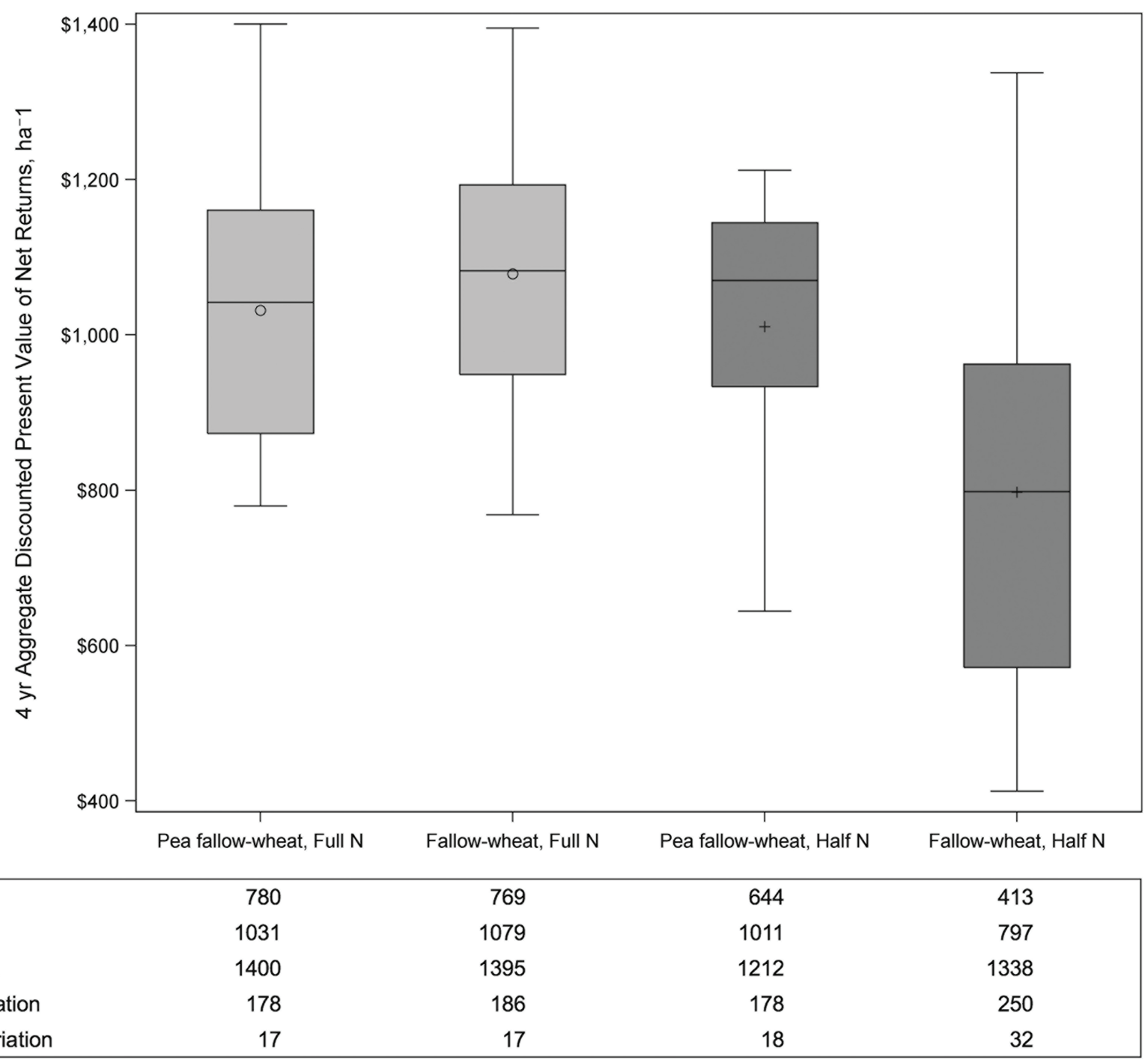

Fig. 2. Boxplots (mean, median interquartile range, minimum, and maximum) of 4 yr discounted present value of net returns in U.S. dollars per hectare to labor and land for pea fallow-wheat and fallow-wheat with full and half N fertility at Bozeman, MT, 2009 to 2012. 
measured on 1 May did not differ among systems in 2009 or 2010 (Table 3). In spring 2011, System 6 had a 0.16 to $0.28 \mathrm{~m}$ shallower soil moisture profile than others. Wheat growth in System 6 in 2010 was observed and measured to be superior, which may have resulted in greater root development and soil water extraction. In 2012, moist soil depth was $0.12 \mathrm{~m}$ greater for the average of wheat-fallow systems ( 1 and 2 ) compared with the average of both pea cover crop-wheat systems (5 and 6). Based on previous measurements of soil water extraction this difference in moist soil depth was small, likely amounting to 10 to $15 \mathrm{~mm}$ of plant available moisture at this location. Soil fertility management did not affect moist soil depth during 2009 to 2012 . Conversely, high $\mathrm{N}$ rate history increased preseed soil nitrate $\mathrm{N}$ in 2009 by $4 \mathrm{~kg} \mathrm{ha}^{-1}(P=0.03)$ and in 2011 by $21 \mathrm{~kg} \mathrm{ha}^{-1}(P<0.01)$ following wheat years in 2008 and 2010 (Table 4). Soil nitrate $\mathrm{N}$ averaged 6 to $22 \mathrm{~kg} \mathrm{ha}^{-1}$ greater in pea-wheat than in the wheat-only systems $(P<0.01)$. This is consistent with many previous reports in semiarid contexts within Saskatchewan and Montana (Miller et al., 2002, 2003, 2006, 2011; Miller and Holmes 2005; Burgess et al., 2012), yet inconsistent with another study in this region (O'Dea et al., 2013).

Table 5 presents the key input costs for each system during 2009 to 2012. Most variation occurred in fertilizer costs, especially between full and half recommended rates of $\mathrm{N}$. This cost difference averaged $\$ 99 \mathrm{ha}^{-1}\left(\$ 40 \mathrm{acre}^{-1}\right)$ for spring wheat in 2010 and $\$ 178 \mathrm{ha}^{-1}\left(\$ 72 \mathrm{acre}^{-1}\right)$ for winter wheat in 2012. Other input costs were greater in 2011 than 2009 for Systems 5 and 6 due to additional herbicide applications to manage downy brome (Bromus tectorum L.) and volunteer wheat in uncompetitive winter pea stands, which suffered winter injury. Additional post-termination herbicide application costs were also incurred in that wet 2011 growing season.

It was excessively wet early in the growing season of 2010, possibly resulting in denitrification or leaching of shallow soil nitrate $\mathrm{N}$ (early wheat growth was visually chlorotic for all systems except 6 , which reached its yield goal at the full rate of $\mathrm{N}$ ), followed by a very dry July, leading to "haying off". In 2010 , wheat yields averaged $0.95 \mathrm{Mg} \mathrm{ha}^{-1}$ greater at the high rate of $\mathrm{N}$ compared with the low rate of $\mathrm{N}$ (Table 6). However, under severe drought in 2012, wheat yields averaged $0.39 \mathrm{Mg} \mathrm{ha}^{-1}$ less at the high rate of $\mathrm{N}$ compared with the low rate of $\mathrm{N}$, due to haying off. Grain protein values averaged 27 and $34 \mathrm{~g} \mathrm{~kg}^{-1}$ greater at the high $\mathrm{N}$ rate compared with the low $\mathrm{N}$ rate in 2010 and 2012, respectively. Grain protein values shown in Table 6 indicated that spring wheat yield potentials for the available rainfall in 2010 were attained at the high rate of $\mathrm{N}$, according to the yield sufficiency indicator of 142 to $150 \mathrm{~g} \mathrm{~kg}^{-1}$ protein reported by Engel et al. $(1999,2006)$ and Selles and Zentner (2001). Conversely at the half $\mathrm{N}$ rate, only System 6 apparently had sufficient $\mathrm{N}$ to optimize spring wheat grain yield. Engel et al. (2006) showed that a protein concentration less than $121 \mathrm{~g} \mathrm{~kg}^{-1}$ indicated yield was likely limited by low $\mathrm{N}$ in winter wheat. By that metric, all systems in 2012 at the high $\mathrm{N}$ rate and the three pulse-wheat systems at both rates had more than adequate $N$. Adjustment of net returns based on low grain test weight served as a trivial factor, and was more than offset by a concomitant increase in grain protein (Table 6).

The pea-wheat system (4) provided the greatest average 4 yr economic returns $\left[\$ 1780 \mathrm{ha}^{-1}\left(\$ 720 \mathrm{acre}^{-1}\right)\right]$ from 2009 to 2012 across all $\mathrm{N}$ fertilizer and protein discount/premium scenarios, despite unremarkable pea grain yields (Table 7). Pea cover crop-wheat systems provided $\$ 139$ to $287 \mathrm{ha}^{-1}$ (\$56-115 acre ${ }^{-1}$ ) greater returns than fallow-wheat systems at the low $\mathrm{N}$ rate scenario, but did not differ from the fallowwheat systems at the high $\mathrm{N}$ rate scenarios. The most remarkable aspect of the comparison among these 4-yr returns is the apparent reduction in returns' uncertainty in the pea-wheat systems compared with wheat monoculture systems. Figure 2 shows the distributional properties of net returns from the pea fallow-wheat systems (5 and 6) and the fallow-wheat systems (1 and 2), indicating that the dispersion of net returns in the pea-wheat systems is statistically indistinguishable from wheat only systems at high $\mathrm{N}$ rates, but at low $\mathrm{N}$ rates, the distribution of pea-wheat net returns is tighter around the central tendency than the wheat only net returns (standard deviation: pea fallow-wheat $=\$ 178 \mathrm{ha}^{-1}$, fallow-wheat $=\$ 250 \mathrm{ha}^{-1}$; coefficient of variation: pea fallow-wheat $=18$, fallow-wheat $=32$ ). These economic results provide similar inferences as those of Zentner et al. (2004). In southwestern Saskatchewan (semiarid, Brown soil zone) a minimum till fully phased rotation study with 3-yr rotation cycles compared a "lentil manure-spring wheat-spring wheat" system with a "fallow-spring wheatspring wheat" system for $12 \mathrm{yr}$. They noted a change in management to earlier tilling of the lentil manure beginning after two 3 -yr cycles $(6 \mathrm{yr})$ and a coincident change in soil $\mathrm{N}$ supplying ability as being important to enabling the cover crop system to yield greater economic returns in 4 of the final 6 yr (with no difference in the other $2 \mathrm{yr}$; averaged $\$ 30 \mathrm{ha}^{-1}$ greater). Notably the economic returns from the first $6 \mathrm{yr}$ of the study (including the transition period) showed the lentil manure system to be an economic loser (averaged \$30 ha ${ }^{-1}$ less). Brandt (1996) also conducted an economic analysis of lentil manure-spring wheat in west central Saskatchewan, and concluded it was uneconomical compared to fallow-spring wheat. However, those results are from a more northerly area in a semiarid to subhumid transition zone where fallow is not commonly practiced.

Our study provides strong suggestive evidence that no-till pea-wheat rotations, which protected wheat yield and/or protein levels under varying $\mathrm{N}$ fertility management, may reduce farmers' exposure to annual variability in aggregate net returns. Farmers value the ability to maintain economic stability and reduce net return uncertainties when growing season rainfall outpaces wheat yield targets, $\mathrm{N}$ fertilizer becomes too costly to apply at full recommended rates, soil $\mathrm{N}$ losses occur (i.e., denitrification, leaching, or volatilization), and in the face of volatile post-harvest market prices and protein discount schedules (Bond and Wonder, 1990; Antle, 1987). We concluded that pea-wheat systems can reduce net return uncertainties relative to wheat-only systems under contrasting $\mathrm{N}$ fertility regimes and variable wheat protein discount schedules in southwestern Montana. These results not only have important economic impacts, but also energetic and environmental implications for potentially lowering $\mathrm{N}$ use in pea-inclusive systems.

\section{ACKNOWLEDGMENTS}

This study was funded by the Montana Ag Experiment Station, the Montana Wheat and Barley Committee, the Montana Fertilizer Advisory Committee, and the USDA CSREES Managed Ecosystems 
Program. We are grateful for the technical magic performed by Rosie Wallander and Terry Rick. Chad Lee, John McDonnell, Dale Flikkema, and Ryan Nelson provided timely and relevant information to estimate fertilizer costs or crop values.

\section{REFERENCES}

Aakre, D. 2013. Custom farm work rates on North Dakota farms, 2012, by North Dakota farming regions. EC499 (revised) North Dakota State Univ. Ext. Serv., Fargo. January 2013. www.ag.ndsu.edu/pubs/agecon/ market/ec499.pdf (accessed 28 Feb. 2014).

Allen, B.L., J.L. Pikul, Jr., J.T. Waddell, and V.L. Cochran. 2011. Long-term lentil green-manure replacement for fallow in the semiarid northern Great Plains. Agron. J. 103:1292-1298. doi:10.2134/agronj2010.0410

Antle, J.M. 1987. Econometric estimation of producers' risk attitudes. Am. J. Agric. Econ. 69:509-522. doi:10.2307/1241687

Biederbeck, V.O., O.T. Bouman, C.A. Campbell, L.D. Bailey, and G.E. Winkleman. 1996. Nitrogen benefits from four green-manure legumes in dryland cropping systems. Can. J. Plant Sci. 76:307-315. doi:10.4141/cjps96-053

Biederbeck, V.O., C.A. Campbell, V. Rasiah, R.P.Zentner, and G. Wen. 1998. Soil quality attributes as influenced by annual legumes used as green manure. Soil Biol. Biochem. 30:1177-1185. doi:10.1016/S0038-0717(97)00150-8

Bond, G., and B. Wonder. 1990. Risk attitudes amongst Australian farmers. Australian J. Agric. Res. Econ. 31:29-44.

Brandt, S.A. 1996. Alternatives to summerfallow and subsequent wheat and barley yield on a Dark Brown soil. Can. J. Plant Sci. 76:223-228. doi:10.4141/cjps96-041

Brown, P.L. 1959. Soil moisture holds the key! Crops Soils, Vol. 11, no. 9. ASA, Madison, WI.

Burgess, M., P. Miller, and C. Jones. 2012. Pulse crops improve energy intensity and productivity of cereal production in Montana, U.S.A. J. Sust. Ag. 36:699-718. doi:10.1080/10440046.2012.672380

Burgess, M.B., P.R. Miller, C.A. Jones, and A. Bekkerman. 2014. Tillage of annual legume cover crops accelerates nitrogen uptake of spring wheat. Agron. J. 106:1497-1508.

Engel, R.E., D.S. Long, and G.R. Carlson. 2006. Grain protein as a postharvest index of nitrogen status for winter wheat in the northern Great Plains. Can. J. Plant Sci. 86:425-431. doi:10.4141/P05-216

Engel, R.E., D.S. Long, G.R. Carlson, and C. Meier. 1999. Method for precision nitrogen management in spring wheat: I. Fundamental relationships. Precis. Agric. 1:327-338. doi:10.1023/A:1009929226268

Ford, G.L., and J.M. Krall. 1979. The history of summerfallow in Montana. Montana Agric. Exp. Stn. Bull. Montana State Univ., Bozeman.

Janzen, H.H. 2001. Soil science on the Canadian prairies-Peering into the future from a century ago. Can. J. Soil Sci. 81:489-503. doi:10.4141/S00-054

Jones, D.B. 1941. Factors for converting percentages of nitrogen in food and feeds into percentages of protein. USDA Circular no. 183. USDA, Washington, DC.

Larney, F.J., C.W. Lindwall, R.C. Izaurralde, and A.P. Moulin. 1994. Tillage systems for soil and water conservation on the Canadian prairie. In: Conservation tillage in temperate agroecosystems, CRC Press, Boca Raton, FL. p. 305-328.

Linfield, L.B. 1902. Report of six year rotation experiment. Montana Agric. Exp. Stn. Bull. Ann. Rep. p. 51-55.
Long, J.A., R.L. Lawrence, P. Miller, and L. Marshall. 2014. Changes in fieldlevel cropping sequences: Indicators of shifting agricultural practices. Agric. Ecosyst. Environ. 189:11-20. doi:10.1016/j.agee.2014.03.015

Miller, P.R., R.E. Engel, and J.A. Holmes. 2006. Cropping sequence effect of pea and pea management on spring wheat in the northern Great Plains. Agron. J. 98:1610-1619. doi:10.2134/agronj2005.0302

Miller, P.R., Y. Gan, B.G. McConkey, and C.L. McDonald. 2003. Pulse crops for the northern Great Plains. 1. Grain productivity and residual effects on soil water and N. Agron. J. 95:972-979. doi:10.2134/agronj2003.0972

Miller, P.R., and J.A. Holmes. 2005. Cropping sequence effects of four broadleaf crops on four cereal crops in the northern Great Plains. Agron. J. 97:189-200. doi:10.2134/agronj2005.0189

Miller, P.R., and J.A. Holmes. 2012. Comparative soil water use by annual crops at a semiarid site in Montana. Can. J. Plant Sci. 92:803-807. doi:10.4141/cjps2011-191

Miller, P.R., E.J. Lighthiser, C.A. Jones, J.A. Holmes, T.L. Rick, and J.M. Wraith. 2011. Pea green manure management affects organic winter wheat yield and quality in semiarid Montana. Can. J. Plant Sci. 91:497-508. doi:10.4141/cjps10109

Miller, P.R., J. Waddington, C.L. McDonald, and D.A. Derksen. 2002. Cropping sequence affects wheat productivity on the semiarid northern Plains. Can. J. Plant Sci. 82:307-318. doi:10.4141/P01-116

O'Dea, J.K., P.R. Miller, and C.A. Jones. 2013. Greening summer fallow with legume green manures: On-farm assessment in north-central Montana. J. Soil Water Conserv. 68:270-282. doi:10.2489/jswc.68.4.270

Pikul, J.L., J.K. Aase, and V.L. Cochran. 1997. Lentil green manure as fallow replacement in the semiarid northern Great Plains. Agron. J. 89:867874. doi:10.2134/agronj1997.00021962008900060004x

Power, J.F. 1991. Growth-characteristics of legume cover crops in a semiarid environment. Soil Sci. Soc. Am. J. 55:1659-1663. doi:10.2136/ sssaj1991.03615995005500060026x

Sarvis, J.T., and J.C. Thysall. 1936. Crop rotations and tillage experiments at the Northern Great Plains field station Mandan, N. Dak. USDA Tech. Bull. 536. USDA, Washington, DC.

SAS Institute. 2008. JMP" 8 Introductory guide. SAS Inst., Cary, NC.

Selles, F., and R.P. Zentner. 2001. Grain protein as a post-harvest index of N sufficiency for hard red spring wheat in the semiarid prairies. Can. J. Plant Sci. 81:631-636. doi:10.4141/P00-101

Tanaka, D.L., D.J. Lyon, P.R. Miller, S.D. Merrill, and B. McConkey. 2010. Soil and water conservation advances in the semiarid northern Great Plains. In: T.M. Zobeck and W.F. Schillinger, editors, Soil and water conservation advances in the United States. SSSA Spec. Publ. 60. SSSA, Madison, WI. p. 81-102.

Willis, R.B. 1980. Reduction column for automated determination of nitrate and nitrite in water. Anal. Chem. 52:1376-1377. doi:10.1021/ac50058a056

Zentner, R.P., C.A. Campbell, V.O. Biederbeck, F. Selles, R. Lemke, P.G. Jefferson, and Y. Gan. 2004. Long-term assessment of management of an annual legume green manure crop for fallow replacement in the Brown soil zone. Can. J. Plant Sci. 84:11-22. doi:10.4141/P02-188

Zollinger, R. 2013 North Dakota weed control guide. W-253. North Dakota State Univ. Ext. Serv., Fargo. January 2013. (www.ag.ndsu.edu/weeds/ weed-control-guides/nd-weed-control-guide-1/wcg-files/18.1-Herb\%20 Comp.pdf (accessed 28 Feb. 2014). 